\title{
TRAINING BY USING ZOOM MEETING TO IMPROVE TEACHING SKILLS AT SDN 017 SUNGAI GANTANG
}

\author{
Jawardi \\ SDN 017 Sungai Gantang, Indragiri Hilir, Indonesia \\ jawardy1972@gmail.com
}

\begin{abstract}
Basic teaching skills are related to some basic and inherent abilities or skills that every teacher must possess and actualize (Mulyasa, 2013; Achdiani and Rusliyani, 2017). For this reason, training was carried out by using Zoom meetings through the Class Action research method in two cycles. The research was conducted at SDN 017 Sungai Gantang, Kecamatan Kempas, Kabupaten Indragiri Hilir which involved 9 (nine) teachers. The research was conducted for 3 months from March to May 2020. The results of the research in cycle I found that the teacher's ability in teaching skills at SDN 017 Sungai Gantang, Kecamatan Kempas, Kabupaten Indragiri Hilir was categorized as good, but there was one teacher who was still in the sufficient category in the skill of asking questions with a score of 65. It was seen that the asking question skills were not seen, in which the teacher asked for explanations and provided the stimulus to students. Similarly, in the next component, namely the skills of opening and closing lessons, there were some teachers who were still missing due to network constraints so they forgot to give openings in lessons. Data in cycle II illustrated that there were 3 teachers got a good category in teaching and 3 teachers got a very good category in doing online learning. This was the impact of training on teaching skills carried out by school principals as a routine activity in improving teachers 'professionalism.
\end{abstract}

Keywords: training, zoom meeting, teaching skills

\section{PELATIHAN DENGAN MENGGUNAKAN ZOOM MEETING DALAM MENINGKATKAN KETERAMPILAN MENGAJAR DI SDN 017 SUNGAI GANTANG}

\begin{abstract}
ABSTRAK
Keterampilan dasar mengajar berkenaan dengan beberapa kemampuan atau keterampilan yang bersifat mendasar dan melekat yang harus dimiliki dan diaktualisasikan oleh setiap guru (Mulyasa, 2013; Achdiani dan Rusliyani, 2017). Untuk itu dilakukan pelatihan dengan menggunakan Zoom meeting dengan menggunakan metode penelitian Tindakan kelas dengan dua siklus, dan tempat penelitian SDN 017 Sungai Gantang Kecamatan Kempas Kabupaten Indragiri Hilir dengan jumlah guru 9 (Sembilan ) orang waktu penelitian selama 3 bulan terhitung bulan Maret sampai dengan Mei 2020. Hasil penelitian pada siklus I Setelah dilakukan pelatihan pada siklus I terlihat kemampuan guru dalam keterampilan mengajar guru di SDN 017 Sungai Gantang Kecamatan Kempas Kabupaten Indragiri Hilir sudah terkategori baik tetapi ada satu orang guru masih kategori cukup pada komponen keterampilan bertanya dengan nilai 65 , terlihat dalam keterampilan bertanya belum terlihat guru meminta penjelasan dan memberikan stimulus kepada siswa. Serta dilihat komponen selanjutnya yaitu keterampilan membuka dan menutup pelajaran ada beberapa guru yang masih terlewatkan disebabkan terkendala jaringan sehingga menjadi lupa dalam memberikan pembukaan dalam pelajaran. data siklus II tergambar kemampuan guru dalam keterampilan mengajar dari 6 orang jumlah guru yang mendapatkan kategori baik sebanyak 3 orang, dan 3 orang guru mendapatkan kategori sangat baik dalam melakukan pembelajaran secara daring. Ini merupakan dampak pelatihan tentang keterampilan mengajar yang dilakukan oleh kepala sekolah sebagai kegiatan rutinitas dalam meningkatkan profesionalitas guru.
\end{abstract}

Kata Kunci: pelatihan, zoom meeting, keterampilan mengajar

\begin{tabular}{|c|c|c|}
\hline Submitted & Accepted & Published \\
\hline 01 Juni 2021 & 08 September 2021 & 17 September 2021 \\
\hline
\end{tabular}

\begin{tabular}{|l|c|l|l|}
\hline Citation & $:$ & Jawardi. (2021). Training by Using Zoom Meeting to Improve Teaching Skills at SDN 017 Sungai Gantang. Jurnal PAJAR \\
\hline
\end{tabular}
(Pendidikan dan Pengajaran), 5(5), 1434-1442. DOI : http://dx.doi.org/10.33578/pjr.v5i5.8488.

\section{PENDAHULUAN}

Keterampilan dasar mengajar berkenaan dengan beberapa kemampuan atau keterampilan yang bersifat mendasar dan melekat yang harus dimiliki dan diaktualisasikan oleh setiap guru (Mulyasa, 2013; Achdiani dan Rusliyani, 2017). Mengajar merupakan proses yang kompleks, tidak sekedar menyampaikan informasi dari guru kepada siswa, banyak kegiatan maupun tindakan yang harus dilakukan, terutama bila diinginkan hasil belajar yang lebih baik pada siswa (Wahyulestari, 2018). Keterampilan dasar mengajar (teaching skills) adalah kemampuan atau 
keterampilan yang bersifat khusus (most specific instructional behaviors) yang harus dimiliki oleh guru, dosen, instruktur atau widyaiswara agar dapat melaksanakan tugas mengajar secara efektif, efisien dan profesional (Usman, 2006). Dengan demikian keterampilan dasar mengajar berkenaan dengan beberapa keterampilan atau kemampuan yang bersifat mendasar dan harus dikuasai oleh tenaga pengajar dalam melaksanakan tugas mengajarnya (Harkati, Sukirman, \& Setiadi, 2021). Guru diharapkan memiliki kinerja yang baik dalam melaksanakan tugasnya di sekolah untuk meningkatkan mutu pendidikan, baik secara individu maupun kelompok. Kinerja guru di sekolah mempunyai peran penting dalam pencapaian tujuan sekolah Hadis dan Nurhayati, 2010).

Perubahan pembelajaran di sekolah dasar pada masa pandemic ini memberikan perubahan yang begitu banyak sampai dengan memberikan pelatihan terhadap guru juga berubah. Dimulai tahun 2019 dengan darurat kesehatan yang sangat mengkhawatirkan dengan tersebarnya suatu virus Covid-19 yang secara langsung diumumkan oleh WHO bahwa virus itu sudah menyebar ke seluruh dunia sampai juga menjangkit negara Indonesia (Azuar, 2021). Peran kepala sekolah disinilah yang lebih memberikan motivasi dan arahan untuk pelaksanaan pembelajaran dengan memberikan pelatihan keterampilan mengajar. Perubahan kegiatan belajar dari ruang kelas kerumah membawa tantangan baru bagi kepala sekolah, guru, dan orang tua (Efnedi, 2021). Kesiapan guru, siswa dan orang tua dalam pembelajaran di rumah ini bervariasi, ada yang siap, dipaksa untuk siap, dan benar-benar tidak siap. Tanpa persiapan, akan sulit bagi orang tua dan anak untuk beradaptasi dengan perubahan sistem dari tatap muka menjadi online dengan memanfaatkan teknologi (Novianti, Puspitasari, \& Maria, 2021).

Penggunaan teknologi memang saat ini tidak akan bisa dihindari setiap orang sudah mulai menggunakan teknologi dari berbagai aspek (Kurniaman, Hidayat, Noviana, Munjiatun, \& Kurniawan, 2020) mengingat teknologi di dalam pendidikan memberikan peran dalam perubahan untuk memudahkan pertukaran informasi dan membuat belajar lebih nyaman sehingga pembelajaran menjadi efektif (Karmiani, 2018). Penggunaan zoom meeting merupakan salah satu arternatif untuk melaksanakan pelatihan maupun pembelajaran saat ini dimasa pandemik yang membatasi tatap muka secara langsung. Untuk mewujudkan sekolah yang berprestasi tentunya dibutuhkan peranan dari kepala sekolah Karena kepala sekolah memiliki peranan terhadap peningkatan mutu sekolah, begitu juga dengan peningkatan mutu kepala sekolah memerlukan peranan dari pengawas karena pengawas sekolah yang juga merupakan pemimpin pendidikan yang bersama-sama kepala sekolah memiliki tanggung jawab terhadap perkembangan sekolah. Kepala sekolah selalu memberikan bimbingan dan arahan serta pengawasan kepada guru dalam melaksanakan proses pembelajaran secara memadai tentu akan menghasilkan hasil belajar yang diharapkan (Ismail, 2018).

\section{KAJIAN TEORETIS}

Pembelajaran merupakan hasil dari memori, kognisi dan metakognisi yang berpengaruh terhadap pemahaman (Huda, 2013). Pembelajaran juga dapat dikatakan sebagai proses transfer informasi dari pengajar kepada peserta didik. Pengajar harus dapat memodifikasi suatu informasi sehingga dapat diterima oleh siswa secara tepat dan meyeluruh. Kemampuan guru dalam menyampaikan informasi dalam proses pembelajaran ini merupakan hal yang tidak mudah. Guru perlu memiliki keterampilan mengajar yang mempuni sehingga siswa dapat belajar dan terlibat (engage) dan tujuan pembelajaran tercapai. Keterampilan dasar mengajara (teaching skills) merupakan keterampilan khusus (most specific instructional behaviors) yang harus dimiliki oleh guru agar dapat melaksanakan tugas mengajar secara efektif, efisien dan professional (Sanjaya, 2013). Ada 8 keterampilan dasar mengajar yang harus dikuasi seorang guru. Adapun 8 keterampilan dasar mengajar itu adalah sebagai berikut.

\section{Keterampilan Bertanya}

Dengan bertanya, seorang guru minta penjelasan dan untuk mengetahui sesuatu. Dalam proses pembelajaran bertanya berperan penting karena pertanyaan guru dapat menstimulus dan 
mendorong siswa untuk berpikir. Pertanyaan yang diajukan guru juga dapat meningkatkan partisipasi dan keterlibatan siswa dalam proses belajar mengajar. Oleh karena itu guru wajib dan melatih keterampilan bertanya pada pembelajaran. Untuk meningkatkan HOTS (Higher Order Thinking Skills) Siswa pertanyaan yang diberikan harus mendalam, mendorong siswa menemukan alasan dan melahirkan gagasan-gagasan kreatif dan alternatif lewat imajinasi siswa.

Guru perlu menghindari kebiasaan seperti: menajawab pertanyaan sendiri, mengulang jawaban siswa, mengulang pertanyaan yang sama, mengajukan pertanyaan dengan jawaban serentak, menentukan siswa yang harus menjawab sebelum bertanya, dan mengajukan pertanyaan ganda. Guru perlu memahami tujuan pertanyaan, seperti: menimbukan rasa ingin tahu, menstimulan fungsi berpikir, mengembangkan keterampilan berpikir, memfokuskan perhatian siswa, mendiagnosis kesulitan belajar siswa dan mengkomunikasikan harapan yang diinginkan oleh guru dari siswa.

\section{Keterampilan Memberikan Penguatan}

Pada jenjang pendidikan dasar, memberikan penguatan harus dilakukan sesering mungkin. Penguatan (reinforcement) adalah segala bentuk respons, baik bersifat verbal maupun nonverbal. Penguatan bertujuan untuk memberikan umpan balik (feedback) kepada siswa atas perbuatanya sebagai dorongan atau koreksi. Penguatan terbagi atas penguatan positif dan penguatan negatif. Penguatan positif bertujuan untuk mempertahankan dan memelihara perilaku positif siswa sedangkan penguatan negatif penguatan untuk menghentikan atau menurunkan perilaku siswa yang tidak menyenangkan.

Penguatan positif untuk siswa SD seperti memberikan pujian, penghargaan dan persetujuan atas perilakunya. Seringkali penguatan juga dapat ditunjukkan dari ekspresi guru, mengajungkan jempol, tersenyum, penguatan dengan sentuhan (mengusap kepala, menepuk pundak atau melakukan tos). Penguatan yang diberikan secara konsisten dapat menumbuhkan motivasi siswa untuk belajar.

\section{Keterampilan Membuat Variasi Stimulus}

Variasi dalam konteks belajar mengajar merujuk pada Tindakan guru yang disengaja atau secara spontan dengan tujuan untuk mengikat perhatian siswa selama pembelajaran berlangsung. Variasi stimulus dapat mengurangi kebosanan siswa dan kembali menarik perhatiannya pada pembelajaran. Bentuk variasi stimulus dalam pembelajaran seperti: Variasi suara (teacher voice), pemusatan perhatian siswa (focusing), kesenyapan/kebisuan guru (teacher silence), kontak pandang dan gerak (eyes contact and movement), gusture/gerak tubuh, ekspresi wajah guru, perpindahan posisi guru dalam kelas dan juga variasi penggunaan media dan alat pengajaran. Beberapa kelas di SD, guru menggunakan yel-yel, misalnya: guru berkata "eyes on me" murid menjawab "eyes on you" atau dengan bertepuk tangan dan sebagainya sehingga siswa tetap dapat terlibat dan mengikuti proses pembelajaran dengan baik

\section{Keterampilan Menjelaskan}

Keterampilan menjelaskan adalah suatu keterampilan menyajikan informasi yang terorganisir secara sistematis sebagai kesatuan yang berarti sehingga peserta didik dapat memahami dengan mudah. Guru perlu memahami prinsip-prinsip menjelaskan seperti: a) penjelasan harus sesuai dengan karakteristik peserta didik; b) penjelasan harus diselingi dengan tanya jawab dengan tetap memperhatikan tujuan pembelajaran; dan c) penjelasan harus disertai dengan contoh yang konkrit, dihubungkan dengan kehidupan sehari-hari dan bermakna. Aspek-aspek dalam menjelaskan materi pembelajaran seperti bahasa yang dipilih haru sederhana, terang dan jelas, bahan yang disajikan harus dipahami dan dikuasai dengan baik dan pokok-pokok yang diterangkan harus disimpulkan diakhir pembelajaran.

\section{Keterampilan Membuka dan Menutup Pelajaran Ada banyak Ahli Public Speking berpendapat bahwa membuka dan menutup kelas merupakan hal yang penting untuk audience karena ini menentukan keberhasilan seorang pembicara/guru/pemakalah. Membuka}


kelas ibarat pesawat yang akan lepas landas sedangkan menutup kelas ibarat pesaw at yang akan mendarat. Oleh karena itu guru perlu mempersiapkan bagian membukan dan menutup kelas dengan sangat baik. Peranan guru dalam pembukaan kelas dan penutupan berpengaruh pada ingatan materi siswa.

Membuka pelajaran (set induction) ialah usaha atau kegiatan yang dilakukan guru untuk menciptakan prokondusi bagi siswa agar mental maupun perhatian terpusat pada apa yang akan dipelajari. Komponen membukan kelas meliputi: menarik perhatian, membangkitkan motivasi, dan apersepsi. Sebagai contoh guru membuka kelas dengan membawa box tertutup yang isinya dirahasiakan, dengan menggerakkan dan sambil bertaya "Siapa yang tahu isi box ini?". Kondisi ini akan sangat menarik perhatian peserta didik sehingga guru dapat dengan mudah melanjutkan pada bagian inti pembelajaran.

Menutup pelajaran (closure) ialah kegiatan yang dilakukan guru untuk mengakhiri proes KBM. Ibarat mendaratkan pesawat, bagian penutup juga perlu dipersiapkan dengan baik, tidak tergesa-gesa atau mendadak ditutup. Komponenkomponen dalam menutup kelas seperti: merangkum kelas, menyampaikan rencana pembelajaran berikutnya, berikan pertanyaan yang membangkitkan rasa ingin tahu untuk mempelajari materi berikutnya, dan diakhri dengan doa. Guru harus menutup pembelajaran dengan semangat dan dapat memberikan pematik sebagai sesuatu yang dinanti-nantikan siswa untuk dipelajari.

Sebagai contoh menutup pelajaran: guru memberikan pertanyaan "apa yang telah kalian pelajari hari ini"? lagu guru mempersilakan beberapa murid untuk menjawab. Guru dapat memberikan kesimpulan di akhir. Lalu guru dapat bertanya "adakah yang pernah melihat hasil kerajinan tangan dari barang bekas?" tahukah kalian bahwa Indonesia masih menjadi negeri diurutan atas yang memproduksi sampah plastik? Apakah hal ini benar?.." minggu depan kita akan belajar bagaimana mengelola barang bekas menjadi barang berkelas!". Berdoa dan kelas berakhir.

\section{Keterampilan Membimbing Diskusi Kelompok Kecil \\ Diskusi kelompok merupakan salah satu} variasi kegiatan pembelajaran yang dapat digunakan dalam proses KBM. Diskusi yang berjalan baik dapat meningkatkan kreativitas dan keterampilan berpikir HOTS. Diskusi merupakan strategi yang memungkinkan siswa menguasai suatu konsep atau memecahkan masalah melalui proses yang memberi kesempatan berpikir, berinteraksi sosial, serta berlatih bersikap positif pada perbedaan pendapat dan membangun kerja sama kelompok.

Guru dapat mempersiapkan kelompok kecil diskusi yang terdiri atas 2-4 orang. Pembagian anggota kelompok terdiri atas siswa dengan kemampuan tinggi, sedang, dan rendah atau mengelompokkan siswa berkemampuan tinggi dengan tinggi, rendah dengan rendah dan sedang dengan sendang. Hal ini dapat disesuaikan dengan kebutuhan dan tujuan pembelajaran yang hendak dicapai. Guru perlu mempersiapkan materi pelajaran dengan sebaik-baiknya sehingga diskusi memberi manfaat bagi peserta didik.

\section{Keterampilan Mengelola Kelas}

Proses pembelajaran di kelas merupakan suatu hal yang komplek. Dikatakan kompleks karena jika ada 25 siswa dalam suatu kelas, maka guru memiliki 25 keunikan dan karakter yang berbeda. Terlebih lagi pembelajaran di sekolah dasar, Guru harus dapat memperhatikan siswa, menyampaikan materi dan mengatasi kegaduhan yang mungkin terjadi saat proses pembelajaran berlangsung.

Keterampilan mengelola kelas menjadi hal yang penting dimiliki guru agar suasana belajar mengajar dapat menunjang efektifitas pencapaian tujuan pembelajaran. Dalam melaksanakan keterampilan mengelola kelas, guru perlu memperhatikan komponen keterampilan yang berhubungan dengan penciptaan dan pemeliharaan kondisi belajar yang optimal (bersifat prefentip seperti: kemampuan guru dalam mengambil inisiatif dan mengendalikan pelajaran) dan keterampilan yang bersifat represif, yaitu keterampilan yang berkaitan dengan respons guru terhadap gangguan siswa yang berkelanjutan 
dengan maksud agar guru dapat mengadakan tindakan remedial untuk mengembalikan kondisi belajar yang optimal.

Keterampilan guru dalam mengelola kelas sangat ditentukan oleh jam terbangnya sebagai guru. Semakin sering guru mengajar di kelas maka semakin meningkatnya keterampilannya dalam mengelola kelasnya, tentu dengan kemauan untuk belajar dan menjadi lebih baik.

\section{Keterampulan Mengajar Kelompok Kecil dan Peroseorangan}

Keterampilan mengajar dalam kelompok kecil di sekolah dasar sering kali dilakukan karena kebutuhan scaffolding dan pendampingan belajar. Hal ini biasanya dialami siswa dengan kebutuhan khusus atau karena kesulitan dalam pelajaran. Kelompok kecil biasanya berkisar 3 sampai 8 orang dan 1 orang untk perorangan. Hal yang penting dalam pembelajaran kelompok kecil ini, guru harus meningkatkan kompetensi sosial dan kompentensi kepribadian. Karena dalam situasi pembelajaran kelompok ini dibutuhkan komunikasi dan hubugan yang akrab sehingga siswa nyaman belajar.

\section{METODE PENELITIAN}

Penelitian ini dilakukan oleh kepala sekolah untuk memberikan penguatan kepada guru tentang keterampilan mengajar. Tempat penelitian SDN 017 Sungai Gantang Kecamatan Kempas Kabupaten Indragiri Hilir dengan jumlah guru 9 (Sembilan ) orang waktu penelitian selama 3 bulan terhitung bulan Maret sampai dengan Mei 2020. Metode penelitian ini diambil dengan menggunakan Penelitian Tindakan Kelas yang dilakukan untuk memperbaiki atau meningkatkan mutu praktik pembelajaran (Hadijah, 2021). Karena kajian yang bersifat reflektif yang dilakukan oleh guru untuk meningkatkan kemampuan esensial dari tindakan- tindakannya dalam melaksanakan tugas dan memperdalam pemahaman terhadap kondisi dalam praktik pembelajaran (Suhardjono, 2007; Rizki, Zufriady, \& Guslinda, 2020).

Teknik pengumpulan data dengan menggunakan teknik observasi dilakukan Ketika guru melakukan pembelajaran secara daring dengan proses supervise di kelas, sehingga setelah dilakukan pelatihan maka akan dinilai dengan menggunakan dua siklus yang berpedoman kepada instrument penelitian 8 standar penilaian. Selanjutnya dikategorikan keterampilan guru sesuai pada table 1 .

Tabel 1. Interval Keterampilan Mengajar Guru

\begin{tabular}{ccc}
\hline No & Klasifikasi & Persentase (\%) \\
\hline 1 & Sangat Baik & $81-100$ \\
2 & Baik & $61-80$ \\
3 & Cukup & $41-60$ \\
4 & Kurang & $21-40$ \\
5 & Kurang Sekali & $0-20$ \\
\hline
\end{tabular}

\section{HASIL DAN PEMBAHASAN}

Pelatihan ini dilakukan untuk meningkatkan kemampuan mengajar guru 8 standar 1) Keterampilan Bertanya; 2) Keterampilan Memberikan Penguatan; 3) Keterampilan Membuat Variasi Stimulus; 4) Keterampilan Menjelaskan; 5) Keterampilan Membuka dan Menutup Pelajaran; 6) Keterampilan Membimbing Diskusi Kelompok Kecil; 7) Keterampilan Mengelola Kelas; dan 8)
Keterampulan Mengajar Kelompok Kecil dan Peroseorangan. Dengan menggunakan zoom meeting sebagai alat untuk kegiatan dikarena kondisi yang tidak memungkinkan dengan dilakukan secara luring. Penelitian ini dilakukan dengan dua siklus yang menjadi data dalam penelitian ini akan terlihat kemampuan keterampilan guru dalam mengajar sesuai dengan tabel 2 di bawah ini. 
Tabel 2. Kemampuan Guru dalam Keterampilan Mengajar Siklus I

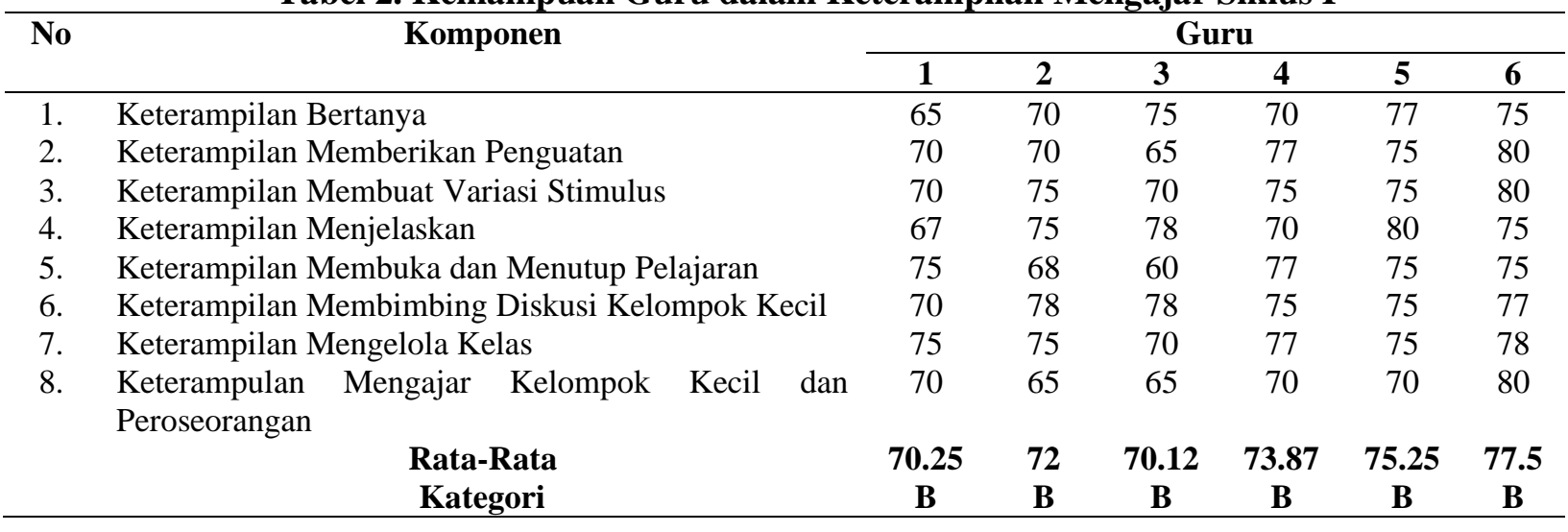

Setelah dilakukan pelatihan pada siklus I terlihat kemampuan guru dalam keterampilan mengajar guru di SDN 017 Sungai Gantang Kecamatan Kempas Kabupaten Indragiri Hilir sudah terkategori baik tetapi ada satu orang guru masih kategori cukup pada komponen keterampilan bertanya dengan nilai 65 , terlihat dalam keterampilan bertanya belum terlihat guru meminta penjelasan dan memberikan stimulus kepada siswa. Serta dilihat komponen selanjutnya yaitu keterampilan membuka dan menutup pelajaran ada beberapa guru yang masih terlewatkan disebabkan terkendala jaringan sehingga menjadi lupa dalam memberikan pembukaan dalam pelajaran. Pembelajaran daring harus melibatkan orang tua dalam proses pembelajaran (Martiyana, Jamaludin, \& Rahman, 2021) untuk mendukung serta memberikan arahan dalam membuka aplikasi dan membantu apabila ada beberapa kendala yang dihadapi oleh siswa. Pada siklus I guru memberikan penekanan kepada orang tua untuk selalu mendampingi dalam kegiatan pembelajaran secara daring maka setelah dilihat kesalahan-kesalahan dalam proses pembelajaran maka dilakukan lagi siklus II dengan memperbaiki proses pembelajaran yang kurang sehingga menghasilkan penilaian seperti pada tabel 3 di bawah ini.

Tabel 2. Kemampuan Guru dalam Keterampilan Mengajar Siklus II

\begin{tabular}{|c|c|c|c|c|c|c|c|}
\hline \multirow[t]{2}{*}{ No } & \multirow[t]{2}{*}{ Komponen } & \multicolumn{6}{|c|}{ Guru } \\
\hline & & 1 & 2 & 3 & 4 & 5 & 6 \\
\hline 1. & Keterampilan Bertanya & 70 & 75 & 85 & 85 & 80 & 80 \\
\hline 2. & Keterampilan Memberikan Penguatan & 75 & 70 & 90 & 80 & 85 & 80 \\
\hline 3. & Keterampilan Membuat Variasi Stimulus & 70 & 75 & 80 & 75 & 75 & 80 \\
\hline 4. & Keterampilan Menjelaskan & 70 & 75 & 78 & 70 & 90 & 80 \\
\hline 5. & Keterampilan Membuka dan Menutup Pelajaran & 75 & 70 & 75 & 80 & 75 & 75 \\
\hline 6. & Keterampilan Membimbing Diskusi Kelompok Kecil & 70 & 78 & 80 & 75 & 85 & 86 \\
\hline 7. & Keterampilan Mengelola Kelas & 75 & 75 & 80 & 80 & 75 & 80 \\
\hline \multirow[t]{3}{*}{8.} & $\begin{array}{l}\text { Keterampulan Mengajar Kelompok Kecil dan } \\
\text { Peroseorangan }\end{array}$ & 70 & 65 & 85 & 80 & 80 & 90 \\
\hline & Rata-Rata & 72 & 73 & 82 & 78.12 & 81 & 81.37 \\
\hline & Kategori & $\mathbf{B}$ & B & SB & B & SB & SB \\
\hline
\end{tabular}

Dari data siklus II tergambar kemampuan guru dalam keterampilan mengajar dari 6 orang jumlah guru yang mendapatkan kategori baik sebanyak 3 orang, dan 3 orang guru mendapatkan kategori sangat baik dalam melakukan pembelajaran secara daring. Ini merupakan dampak pelatihan tentang keterampilan mengajar yang dilakukan oleh kepala sekolah sebagai 
kegiatan rutinitas dalam meningkatkan profesionalitas guru. Proses pembelajaran tidak akan lepas dari peran guru sebagi fasilitor yang membawa konsekuensi terhadap perubahan pola hubungan guru siswa, yang semula lebih bersifat atasan bawahan beralih menjadi hubungan kemitraan (Karsono, 2021). Kompetensi guru merupakan kebulatan penguasaan pengetahuan, keterampilan, dan sikap yang ditampilkan melalui unjuk kerja. Kepmendiknas No. 045/U/2002 menyebutkan kompetensi guru sebagai seperangkat tindakan cerdas dan penuh tanggung jawab dalam melaksanakan tugas-tugas sesuai dengan pekerjaan tertentu. Jadi kompetensi guru dapat dimaknai sebagai kebulatan pengetahuan, keterampilan dan sikap yang berwujud tindakan cerdas dan penuh tanggung jawab dalam melaksanakan tugas sebagai pelaksana pembelajaran (Herlina, 2018).

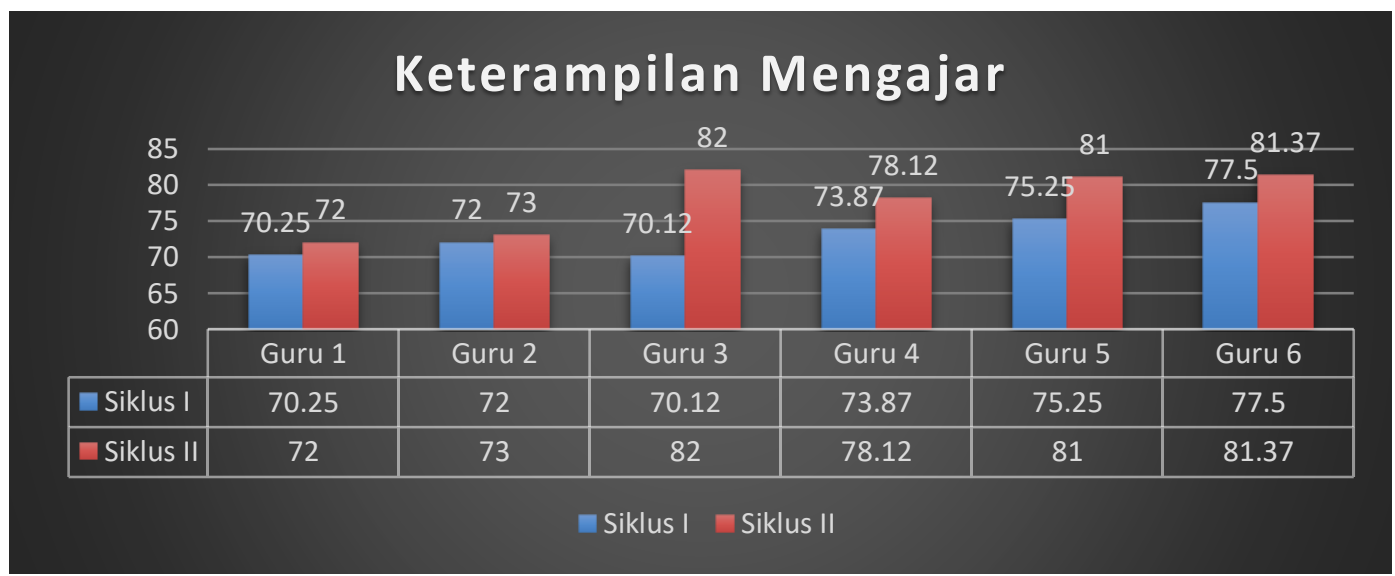

Gambar 1. Peningkatan Kemampuan Guru dalam Keterampilan Mengajar

Terlihat pada gambar 1 pada siklus I dan siklus II guru mengalami peningkatan serta pembelajaran setiap siklus dari kekuranganya diperbaiki. Keterampilan mengelola kelas menjadi hal yang penting dimiliki guru agar suasana belajar mengajar dapat menunjang efektifitas pencapaian tujuan pembelajaran. Dalam melaksanakan keterampilan mengelola kelas, guru perlu memperhatikan komponen keterampilan yang berhubungan dengan penciptaan dan pemeliharaan kondisi belajar yang optimal (bersifat prefentip).

\section{SIMPULAN DAN REKOMENDASI}

Kesimpulan dalam penelitian ini bahwa pelatihan dengan menggunakan zoom meeting sebagai sarana penyampaian kegiatan terlihat efektif dalam meningkatkan kemampuan guru dalam keterampilan mengajar, ini terlihat pada rata-rata guru dalam per siklus mengalami peningkatan yang signifikan dengan dibimbing oleh kepala sekolah untuk memberikan masukan dalam memperbaiki setiap kelemahan dalam mengajar. Saran untuk guru harus selalu menerima masukan yang sifatnya membangun serta memberikan yang terbaik dalam mengajar sehingga siswa lebih tertarik dalam pembelajaran dan juga mampu meningkatkan hasil belajar yang lebih baik lagi.

\section{DAFTAR PUSTAKA}

Achdiani, Y., dan Rusliyani, D. A. (2017). Pengetahuan Keterampilan Dasar Mengajar dalam Menyiapkan Guru Sekolah Menengah Kejuruan. TEKNOBUGA, 5(2), 34-43.

Azuar, A. (2021). The Implementation of Discussion Method through Zoom Meeting for PKN Learning during the Pandemic Period. Jurnal PAJAR (Pendidikan dan Pengajaran), 5(3), 703$709 . \quad$ DOI http://dx.doi.org/10.33578/pjr.v5i3.8396

Efnedi, S. (2021). Improving Social Sciences 
Learning Outcomes through Online Learning at SDN 005 Kempas Jaya. Jurnal PAJAR (Pendidikan dan Pengajaran), 5(3), 717-722. DOI : http://dx.doi.org/10.33578/pjr.v5i3.8399

Hadis, A, dan Nurhayati, B. (2010). Manajemen Mutu pendidikan. Bandung: Alfabeta.

Huda, M. (2013). Model-model Pengajaran dan Pembelajaran. Yogyakarta: Pustaka Pelajar.

Harkati., Sukirman., \& Setiadi, G. (2021). Improving Teachers' Performance through Headmasters' Transformational Leadership and Motivation at Public Elementary Schools. Jurnal PAJAR (Pendidikan dan Pengajaran), 5(3), 526535. DOI

http://dx.doi.org/10.33578/pjr.v5i3.8136

Hadijah. S. (2021). Improving Teachers' Skills in Active, Creative, Effective, and Fun (PAKEM) Learning through Training and Guidance Activities (LATBIM). Primary: Jurnal Pendidikan Guru Sekolah Dasar, 10 (2), 374-383. DOI: http://dx.doi.org/10.33578/jpfkip.v10i2. 8267.

Herlina, H. (2018). Meningkatkan Kompetensi Guru Dalam Menyusun Model Pembelajaran Melalui Workshop Di SD Negeri 009 Seberang Teluk Kecamatan Kuantan Tengah Kabupaten Kuantan Singingi. Jurnal PAJAR (Pendidikan dan Pengajaran), 2(5), 812- 819.

Ismail, R. R. (2018). Penerapan Supervisi Akademi Untuk Meningkatkan Motivasi Berprestasi Guru SD Negeri 009 Teluk Pauh Kecamatan Cirenti. Jurnal PAJAR (Pendidikan dan Pengajaran), 2(5), 820826.

Kurniaman, O., Hidayat, M. L., Noviana, E., Munjiatun, M., \& Kurniawan, K. (2020). The Validation of LIAA (Linguistic Intelligence Assessment Android) Development In Elementary School. Profesi Pendidikan Dasar, 7(2), 162170.
Karmiani, S. (2018). Penggunaan Media Komik Berbahasa Inggris Sebagai Upaya Meningkatkan Kemampuan Membaca Pemahaman Bahasa Inggris Pada Siswa Kelas VIII SMPN 3 Teluk Kuantan. Jurnal Pajar (Pendidikan dan Pengajaran), 2 (6), 883- 890. DOI: http://dx.doi.org/10.33578/pjr.v2i6.6514

Karsono. (2021). Implementing Workshops To Improve Teachers' Ability To Utilize Computers In Teaching Process At Smp Negeri 1 Kubu Rokan Hilir. Primary: Jurnal Pendidikan Guru Sekolah Dasar, 10 (1), 243 - 250. DOI: http://dx.doi.org/10.33578/jpfkip.v10i1. $\underline{8228}$.

Mulyasa. (2013). Menjadi Guru Profesional Menciptakan Pembelajaran Kreatif dan Menyenangkan. Bandung: PT Remaja Rosdakarya.

Martiyana, E. P., Jamaludin, U., \& Rahman, I. U. (2021). Teachers' Role in Building the Character of Confidence in Online-Based Thematic Learning. Primary: Jurnal Pendidikan Guru Sekolah Dasar, 10 (1), 79 - $93 . \quad$ DOI: http://dx.doi.org/10.33578/jpfkip.v10i1. 8076.

Novianti, R., Puspitasari, E., \& Maria, I. (2021). Parents' Involvement in Children's Learning Activities during the Covid-19 Pandemic. Jurnal PAJAR (Pendidikan dan Pengajaran), 5(2), 384-390. DOI : http://dx.doi.org/10.33578/pjr.v5i2.8220

Rizki, H.A., Zufriady., \& Guslinda. (2020). Utilizing Jigsaw Method to Improve Learning Activities and Students' History Learning Outcome at Class XII IPS (Social Science) of SMA Negeri 10 Pekanbaru. Jurnal PAJAR (Pendidikan dan Pengajaran), 5(1), 194-201. DOI : http://dx.doi.org/10.33578/pjr.v5i1.8226

Sanjaya, W. (2013). Strategi Pembelajaran Berorientasi Standar Proses Pendidikan. Jakarta: Kencana. 
Suhardjono. (2007). Penelitian Tindakan Kelas. Jakarta: Bumi Aksara.

Usman, M. U. (2006). Menjadi Guru Profesional. Bandung : Remaja Rosdakarya.

Wahyulestari, M. R. D. (2018). Ketrampilan Dasar Mengajar Di Sekolah Dasar. ROSIDING Seminar Nasional Pendidikan Era Revolusi "Membangun Sinergitas dalam Penguatan Pendidikan Karakter pada Era IR 4.0” Universitas Muhammadiyah Jakarta, Indonesia, 24 Maret 2018 ISSN : 2621-6477. 